\title{
IAMJ
}

INTERNATIONAL

AYURVEDIC

MEDICAL JOURNAL

ISSN: 2320-5091

Impact Factor: 6.719

\section{ESTIMATION OF CONSUMERS VIEW ON CONCOMITANT USE OF DRUGS AND CREATING ITS AWARENESS: AN ONLINE SURVEY}

\author{
Swati Rajendra Dhande ${ }^{1}$, Shifa Asfaq Surti ${ }^{2}$, Ravi Ashok Vyas ${ }^{3}$ \\ ${ }^{1}$ Assitant Professor, Department of Pharmacology, Bharati Vidyapeeth College of Pharmacy, Navi Mumbai, \\ Maharashtra, India \\ ${ }^{2,3}$ M.Pharmacy, Department of Pharmacology, Bharati Vidyapeeth College of Pharmacy, Navi Mumbai, \\ Maharashtra, India
}

Corresponding Author: swati.dhande@ bvcop.in

\section{https://doi.org/10.46607/iamj0509102021}

(Published Online: October 2021)

Open Access

(C) International Ayurvedic Medical Journal, India 2021

Article Received: 26/09//2021 - Peer Reviewed: 07/10/2021 - Accepted for Publication: 08/10/2021

\section{Check for updates}

\section{ABSTRACT}

Objective: To evaluate awareness among consumers regarding concomitant use of drugs and Herb-Drug interaction. Method: This was a cross-sectional survey, carried out over 2 months. The study was carried among 500 respondents and a questionnaire was sent using google form. Result: About $41 \%$ responded with their preference of medication as allopathy, whereas $37 \%$ consume both medications and $22 \%$ preferred herbal. Indications on concomitant use of drugs show that out of $100 \%$ respondent who consumes both medications, $94 \%$ knows the duration of therapy. Reports on consultation to physician show that out of $100 \%$ respondent who consumes both medications $87 \%$ do consult their physician before use. Among 500 respondents, $60 \%$ are aware of Herb-Drug interaction (HDI) out of which only $9.2 \%$ have faced HDI. Conclusion: The result indicates a need to conduct more awareness on concomitant use of drugs and HDI to minimize the effect on consumers' health.

Keywords: Herbal, Concomitant, Self-medication, HDI. 


\section{INTRODUCTION}

Herbs are ancestrally used by millions of people as medicine in developed and developing nations considering that they are safe and reliable. In Today's era "Herbal Renaissance" has been followed by people all over the world. People now have the erroneous belief that herbal products are superior to synthetically manufactured products. Few consumers even showed dissatisfaction with the results from orthodox pharmaceuticals and the belief that herbal medicines might be effective in the treatment of certain diseases where conventional therapies and medicines have proven to be ineffective.[1] Also, the arbitrary dependence on Allopathic medicine is over and people are returning to the naturals with the hope of safety and security. There are different forms of herbal medicines used in India of which Ayurveda is commonly practised and used among the Indian population for various disorders. As per literature Ayurveda originated from India and is being practised here for more than 5000 years.[2] As a branch of pharmaceuticals people often consumes it without prior consulting to physician consultation, this gives rise to concomitant use and eventually lead to herb-drug interaction.[3] During the latter part of the twentieth century, increasing interest in self-care resulted in enormous growth in the popularity of traditional healing modalities, including the use of herbal remedies. Allopathic medicine is considered an authentic medicinal branch since is used all over the world due to its symptomatic nature. For eras, it has been the preferred treatment of choice during emergency conditions or for various disease ailments.[4] Consumers often buy several Over-counter drugs (OTC) without prior consultation of doctors regarding their simultaneous consumption of the prescribed drugs. Which over some time may lead to individual tolerance to recalibrate and medications desired effect will be deficient. This creates a need for more medications; an endless cycle begins.[5] The reason for selfmedication was patients being uncomfortable about discussing their medical problems and fear of lack of confidentiality in handling their health information, fear of possible misdiagnosis The lack of time to see a physician; this is usually a reason where prior visit did not yield any positive experience.[6]

Herb-drug interaction leads to a pharmacological modification. Herbal medicines consist of mixtures of the active ingredient, such combinations of the many substances that increases the likelihood of drug interactions. Hence, theoretically, the likelihood of herb-todrug interactions is above drug-to-drug interactions, if only because synthetic drugs usually contain single chemical entities. According to literature, it has been observed that geriatrics patients are more prone to concomitant use that may lead to herb-drug interaction. The drug used along with herbs may show pharmacodynamics and pharmacokinetic interactions, therapeutic failure and several adverse effects.[1] The ultimate goal of this article is to raise awareness among consumers regarding this topic and protect their health. This article aims to provide consumers' views on the concomitant use of herbal and allopathic medicine and regarding the interactions between herbal remedies and prescribed drugs.

\section{Material and Methods}

\section{1: Participants:}

The study was designed as a cross-sectional questionnaire-based online survey. The questionnaire was sent via Facebook and WhatsApp groups. All data were collected from April to June 2020. The survey was completed between 500 respondents of which 181 were females and 319 were males aged between 15 to 45 and above years.

\section{2: Materials:}

\section{1: Demographic Questionnaire}

A demographic questionnaire was designed for the current study to collect relevant personal data. Personal Data included gender \& age parameters.

\section{2: Survey-based questionnaire}

Questionnaires were drafted based on the above objectives. It consists of various factors such as system preference, herb-drug interaction, self-medication, etc.

\section{3: Statistical Analysis:}

The statistical calculations were performed using the chi-square test in SPSS (IBM SPSS Statistics for Windows, Version 26.0 Armonk, NY: IBM Corp., 2019) 
and the descriptive analysis in the form of frequency and percentages was calculated. We applied a chisquared test $\left(\chi^{2}\right)$, and age was considered as a factor of comparison with each question where $P<0.05$ was considered statistically significant.

\section{RESULTS}

Out of a total of 500 eligible participants. The pattern of response was $64 \%$ males and $36 \%$ females. Most of the population were in the age group of 15-30 years (46.20\%), 30-45 years (38.6\%) and above 45 years (15.20\% (Table 1)

According to the survey, it was observed that $81 \%$ of respondents gave affirmative responses and people of all age groups know the difference between herbal and allopathic medicine which was found to be statistically significant $\left(\mathrm{P}=0.00^{*}\right)$. As shown in (Fig.1) the results obtained were based on consumers' preferences. Over $41 \%$ and $22 \%$ of respondents preferred allopathic and herbal medicine respectively, the data was found to be significant for all age groups. People who consume herbal and allopathic medications were given few options as to why they prefer that. According to (Table 2) people who preferred herbal majorly consume it because it causes fewer side effects and people who consume allopathic prefer it since it acts fast. In (Fig.2) both case results were compared with all age groups. Results for age group 35-45 years of allopathic shows significant results $(\mathrm{P}=0.001 *)$

The objective of this survey was to find usage of concomitant drugs, result interpreted that out of $100 \%$ of respondents only $6.4 \%$ of respondents consume both herbal and allopathic medicine. When results were compared in different age groups, respondents between 15-30 years of age showed major consumption that is $4.2 \%$. But surprisingly it was found that out of that $6.4 \%$ it was found that $3.6 \%$ of respondents do not consume both medications for a particular disease. Consumption of drugs concerning the duration of therapy was considered as a factor of evaluation, out of $6.4 \% 6 \%$ consume drugs at a specific interval of time and not simultaneously. The result obtained in all age groups was found to be statistically significant $(\mathrm{P}=0.032 *)$. Self-medicating respondents were questioned and their review on consultation with a physician before consuming it. Results show that out of $6.4 \%, 5.6 \%$ of respondents do consult their physician. The age group from 15-30 years shows the highest response of $3.4 \%$ of those who self-medicate. Friends and families (40\%) were the most common sources of information about herbals and supplements. The age group of 30-45 years shows the highest usage of $18 \%$. The result obtained was found to be statistically significant $\left(\mathrm{P}=0.047^{*}\right)$. Physician advice on concomitant use of drugs and discussion on patient's medical history was also an aspect. According to the result obtained $72 \%$ of respondents' medical history was not considered. Also, $65 \%$ of respondents gave an affirmative response on getting advised by their physician. Specifically, awareness of Herb-Drug interaction was examined among people. The result indicated that $60 \%$ of people are aware of it. But people with an age group of 45and above are least aware of it. According to (Fig.3), people with an age group of 15-30 years are more likely to face Herb-Drug interaction.

$* \mathrm{P}<0.05 ; * * \mathrm{P}<0.01 ; * * * \mathrm{P}<0.001$ 
Figure 1: Participant's view on the preference of medications

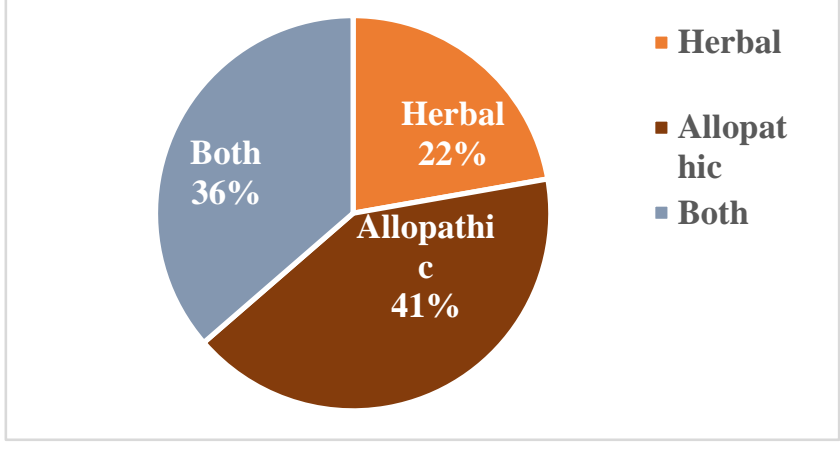

$\chi^{2}$ value - 22.74, $P$ value- $0.001 * * *$

Figure 2: Comparison between age groups on the use of herbal and allopathic

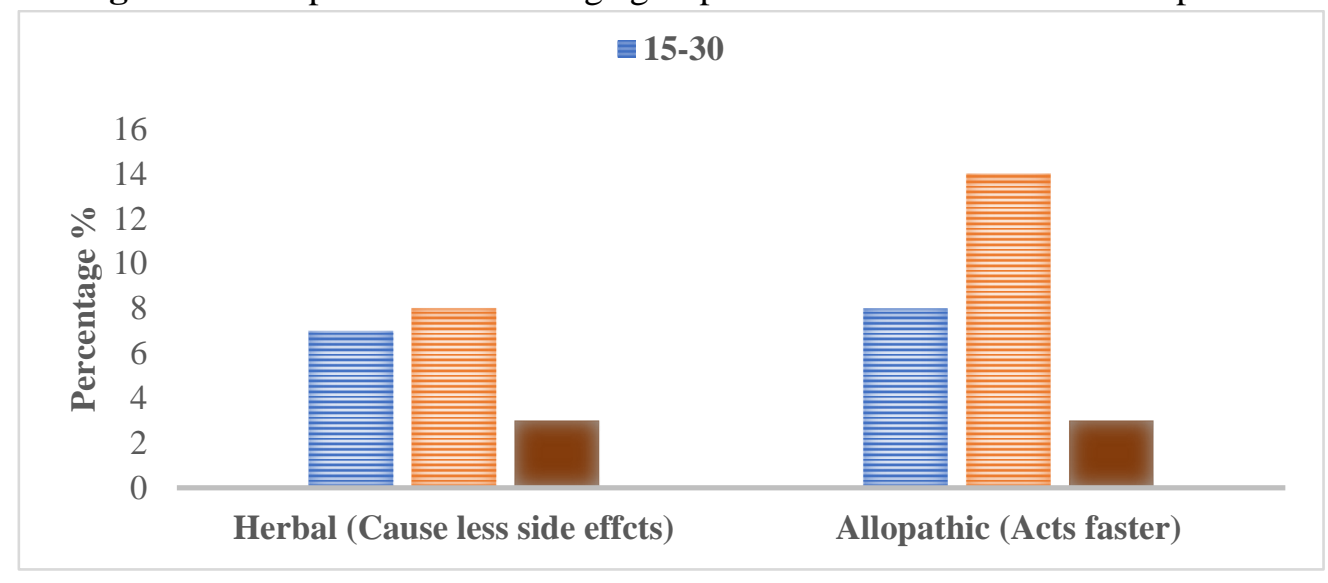

Figure 3: Awareness on Herb-Drug Interaction (HDI)

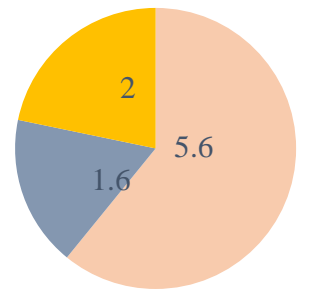

$\square$ 15-30 years $\square 30-45$ years $\square$ Above 45 years

\section{DISCUSSION}

The findings revealed that $42 \%$ of the consumers preferred Allopathic medicines in comparison with Ayurveda $22 \%$. According to Hemant katote, the findings also show similar results that are $72.88 \%$ of the consumers preferred Allopathic medicines in comparison with Ayurveda $27.11 \%$. The results of the study showed that a majority of the study population relies on allopathic medications.[7] Even the elderly who once used home remedies or herbal medicine now consume allopathic medicine. Which ultimately results in dependency and the body often becomes tolerant.[4] The solution is to educate people more about how to avoid self-medication. The result further showed that 
people were aware of the concomitant use of drugs. It was found that herbal medicines were used more by males than females in this study. However, Kristoffersen et.al. showed that women were more frequent users of herbal medicines.[8]

Furthermore, the respondents felt that herbal medicines were mostly preferred over western medicine. since they are easily available and have minimal side effects. Martins Ekor has put forward the factors that affect the increase in usage of herbal medicines.[1] This study shows that the strongest impact of the use of herbal medicines was friends and family. This was like a study conducted by Hon et.al., which showed that the common source of information among traditional Chinese medicine users was family and friends. Similar reasons were identified by Aziato and Antwi and Parle and Bansal such as perceived ineffectiveness of western medicine, adopting a deductive approach based on unreliable information, that is, "it worked for my friend or relative" $[9,10]$. The physician often is more concerned about drug-drug interaction, but people often consult general physicians for general diseases which more commonly leads to HDI. According to the above findings, it is observed that physicians, pharmacists, and health care teams should create awareness on self-medication and concomitant drugs to avoid such interactions which can cause therapeutic failure and severe adverse effects on human health.

\section{CONCLUSION}

The findings of the study signify that every participant has a different medical approach. From the further findings, it is observed that self-medication is increasing day by day, which corresponds to the concomitant use of drugs and eventually leads to interactions. There is a need to conduct an awareness program on selfmedication and concomitant use of drugs to minimize unwanted effects and therapeutic failure.

\section{REFERENCES}

1. Ekor M. The growing use of herbal medicines: Issues relating to adverse reactions and challenges in monitoring safety. Front Neurol. 2014;4 JAN(January):1-10.

2. Bhat BB, Udupa N, Ligade VS, Khan S, Sreedhar D. Assessment of knowledge and attitude of patients on herbal medicine use in Udupi Region, Karnataka, India. Trop J Pharm Res. 2019;18(1):117-21.

3. Fullas F. A Survey on the Use of Complementary and Alternative Medicine Among Ethiopian Immigrants in the USA. J Complement Med Altern Healthc. 2017;1(4):1-7.

4. Blum EM. Allopathic Medicine's Influence on Indigenous Peoples in the Kumaon Region of India. Butl J Undergrad Res. 2018;4(3).

5. Article R. Self-medication: A current challenge. 2014;5(1):19-23.

6. Sunil J. General awareness and relative popularity of allopathic, ayurvedic and homoeopathic systems. 2015;(November 2008).

7. Katole H. EasyChair Preprint Why patients prefer allopathy and ayurvedic therapy in India? 2019;

8. Kristoffersen AE, Stub T, Salamonsen A, Musial F, Hamberg K. Gender differences in prevalence and associations for use of CAM in a large population study. 2014;1-9.

9. Aziato L, Antwi HO. Facilitators and barriers of herbal medicine use in Accra, Ghana: an inductive exploratory study. BMC Complement Altern Med [Internet]. 2016;1-9. Available from: http://dx.doi.org/10.1186/s12906-016-1124-y

10. Parle M, Bansap N. Herbal Medicines: Are they safe? 2005.

Table 1: Demographics Characteristics of Respondents.

\begin{tabular}{|l|l|l|}
\hline Demographics characteristics & Number of Participants & Frequency In percentage \\
\hline Gender & \multicolumn{2}{|l|}{} \\
\hline Male & 319 & 63.80 \\
\hline Female & 181 & 36.20 \\
\hline Age (in years) & & \\
\hline $15-30$ & 231 & 46.20 \\
\hline $30-45$ & 193 & 38.60 \\
\hline Above 45 & 76 & 15.20 \\
\hline
\end{tabular}


Table 2: Survey Questionnaire and observations

\begin{tabular}{|c|c|c|c|c|c|c|}
\hline \multirow[t]{2}{*}{ Questions } & \multirow[t]{2}{*}{ Responses } & \multicolumn{3}{|c|}{ Age in years } & \multirow{2}{*}{$\begin{array}{l}\text { Total partici- } \\
\text { pants \% }\end{array}$} & \multirow{2}{*}{$\begin{array}{l}\text { Chi- } \\
\text { square }(P)\end{array}$} \\
\hline & & $15-30$ & $30-45$ & Above 45 & & \\
\hline \multirow{2}{*}{$\begin{array}{l}\text { 1. Do you know the difference between } \\
\text { Herbal and Allopathic medicine? }\end{array}$} & Yes & 41.0 & 30.60 & 9.6 & 81.20 & \multirow[b]{2}{*}{$\begin{array}{c}25.28 \\
(0.001 * * *)\end{array}$} \\
\hline & No & 5.2 & 8.0 & 5.6 & 18.80 & \\
\hline \multirow{3}{*}{$\begin{array}{l}\text { 2. If herbal, } \\
\text { then why? }\end{array}$} & Causeless side effects & 7.0 & 7.6 & 2.6 & 17.20 & \multirow{3}{*}{$\begin{array}{l}10.08 \\
(0.25)\end{array}$} \\
\hline & Easily available & 1.6 & 0.8 & 0.8 & 3.2 & \\
\hline & Permanently Cure disease & 0.2 & 0 & 0 & 0.2 & \\
\hline \multirow[t]{3}{*}{ 3. If Allopathic, then why? } & Acts Faster & 8.2 & 14.4 & 3.6 & 26.2 & \multirow{3}{*}{$\begin{array}{c}32.76 \\
(0.001 * * *)\end{array}$} \\
\hline & $\begin{array}{l}\text { Can be taken during a med- } \\
\text { ical emergency }\end{array}$ & 5.6 & 6.2 & 2 & 13.80 & \\
\hline & Reliable & 0.2 & 0 & 0 & 0.2 & \\
\hline \multirow{3}{*}{$\begin{array}{l}\text { 4. Do you take any Herbal or Allopathic } \\
\text { medicine }\end{array}$} & Yes & 13.8 & 14.4 & 12 & 40.20 & \multirow{3}{*}{$\begin{array}{c}64.79 \\
(0.001 * * *)\end{array}$} \\
\hline & No & 28 & 22.8 & 2.4 & 53.2 & \\
\hline & Both & 4.2 & 1.4 & 0.08 & 6.4 & \\
\hline \multirow{2}{*}{$\begin{array}{l}\text { 5. Do you take both herbal and Allopathic } \\
\text { medicine for a particular disease }\end{array}$} & Yes & 1.4 & 0.6 & 0.6 & 2.6 & \multirow{2}{*}{$\begin{array}{l}8.01 \\
(0.23)\end{array}$} \\
\hline & No & 2.6 & 0.8 & 0.2 & 3.6 & \\
\hline \multirow{2}{*}{$\begin{array}{l}\text { 6. If you consume both, what time do you } \\
\text { take }\end{array}$} & Simultaneously & 0.2 & 0.6 & 0.2 & 1.0 & \multirow{2}{*}{$\begin{array}{c}10.55 \\
(0.032 *)\end{array}$} \\
\hline & At a specific interval & 4.0 & 0.8 & 0.6 & 5.4 & \\
\hline \multirow{2}{*}{$\begin{array}{l}\text { 7. If both, have you consulted your physi- } \\
\text { cian }\end{array}$} & Yes & 3.4 & 1.4 & 0.8 & 5.6 & \multirow{2}{*}{$\begin{array}{l}7.640 \\
(0.266)\end{array}$} \\
\hline & No & 0.6 & 0 & 0 & 0.6 & \\
\hline \multirow{2}{*}{$\begin{array}{l}\text { 8. Does your } \\
\text { physicians ask you about what all herbal medi } \\
\text { you consume before prescribing }\end{array}$} & Yes & 15.6 & 6.0 & 6.2 & 27.80 & \multirow{2}{*}{$\begin{array}{c}24.92 \\
(0.001 * * *)\end{array}$} \\
\hline & No & 30.6 & 32.6 & 9.0 & 72.2 & \\
\hline \multirow{2}{*}{$\begin{array}{l}\text { 9. Does your physician gives some instruc- } \\
\text { tion/ advice on concomitant use of drugs? }\end{array}$} & Yes & 29.0 & 26.0 & 10.6 & 65.6 & \multirow{2}{*}{$\begin{array}{c}1.66 \\
(0.436)\end{array}$} \\
\hline & No & 17.2 & 12.60 & 4.6 & 34.4 & \\
\hline \multirow{2}{*}{$\begin{array}{l}\text { 10. Have you ever faced any drug interac- } \\
\text { tion/ reaction }\end{array}$} & Yes & 5.6 & 1.6 & 2.0 & 9.2 & \multirow[b]{2}{*}{$\begin{array}{c}11.17 \\
\left(0.025^{*}\right)\end{array}$} \\
\hline & No & 40.6 & 36.8 & 13.2 & 90.6 & \\
\hline \multirow{2}{*}{$\begin{array}{l}\text { 11. Do you consume any Herbal drugs by } \\
\text { yourself or consulted by your friends? }\end{array}$} & Yes & 16.2 & 17.8 & 7.6 & 41.6 & \multirow[b]{2}{*}{$\begin{array}{c}9.64 \\
(0.047 *)\end{array}$} \\
\hline & No & 30 & 0.6 & 7.6 & 58.2 & \\
\hline
\end{tabular}

$* \mathrm{P}<0.05 ; * * \mathrm{P}<0.01 ; * * * \mathrm{P}<0.001$

\section{Source of Support: Nil}

\section{Conflict of Interest: None Declared}

How to cite this URL: Swati Rajendra Dhande et al: Estimation Of Consumers View On Concomitant Use Of Drugs And Creating Its Awareness: An Online Survey. International Ayurvedic Medical Journal \{online\} 2021 \{cited October 2021\} Available from: http://www.iamj.in/posts/images/upload/2318_2323.pdf 